\title{
Does Radical Trachelectomy Represent a Realistic Approach in Early Stage Cervical Cancer?
}

\author{
Georgios Androutsopoulos*, Georgios Michail, Panagiotis Panas and Georgios Adonakis \\ Department of Obstetrics and Gynaecology, University of Patras, Greece
}

Received: October 08, 2018; Published: November 15, 2018

*Corresponding author: Georgios Androutsopoulos MD, PhD, Assistant Professor, Division of Gynaecological Oncology, Department of Obstetrics and Gynaecology, University of Patras, Medical School, Rion 26504, Greece

\section{Editorial}

Nowadays, cervical cancer (CC) represents a major clinical problem as it is the most common malignancy of the female reproductive system and the fourth most common cancer in the general female population [1,2]. The disease most commonly affects young patients, sometimes before completion of childbearing [1,2]. In this case, the type and extend of surgical treatment should be carefully individualized based on disease stage, histologic subtype, fertility issues and performance status [3-8].

Especially in young patients with FIGO stage IB1 CC and strong desire for fertility preservation, radical trachelectomy represents a realistic treatment option [3,8-13]. The procedure was initially described in 1994 by Daniel Dargent as a vaginal operation [9,14]. Few years later, Richard Smith proposed the abdominal approach as an alternative [15]. The selected patients should have tumor size less than $2 \mathrm{~cm}$, no involvement of the upper endocervical canal and negative pelvic and para-aortic lymph nodes [3,8-13,1618]. Moreover, all patients should have a very detailed counseling regarding disease recurrence, oncologic outcome, fertility and pregnancy issues and perinatal outcome $[3,5-8,11,13,18-20]$.

However, radical trachelectomy should not be offered in patients with aggressive (small cell neuroendocrine carcinoma) or potentially aggressive (gastric type adenocarcinoma, minimal deviation adenocarcinoma) histologic subtypes of CC, even at early stage disease $[3,8,10,13,21-23]$. Preoperatively all patients should have a thorough investigation with pelvic MRI, examination under anesthesia and cystoscopy, in order to assess tumor size as well as extent and proximity to internal cervical os [3,8,12,24-26]. The procedure could be performed using either the vaginal or the abdominal approach $[8,9,15,27]$. Pelvic lymphadenectomy with or without SLN mapping, should be performed before starting radical trachelectomy $[8,9,27,28]$. The excised lymph nodes should be examined using ultrastaging approach and in case of metastasis, the operation should be abandoned [8,9,27-29].

In vaginal radical trachelectomy the cervix, upper vagina and paracolpos/para-vaginal tissues should be excised en bloc, as in a type B radical hysterectomy $[3,8,9]$. Moreover, pelvic lymph nodes could be excised laparoscopically [9]. Respectively, in abdominal radical trachelectomy the cervix, upper vagina $(1-2 \mathrm{~cm})$, parametrium and paracolpos/para-vaginal tissues should be excised en bloc, as in a type $\mathrm{C}$ radical hysterectomy $[3,8,11,15,27]$. Abdominal operation represents a less conservative approach and provides wider parametrial resection compared with vaginal procedure $[3,8,11,15-17,27,30]$. The resection margins of the provided surgical specimen should be examined in detail with multiple frozen sections $[8,29,31]$. In case of clear resection margins to the endocervix, the excisional procedure has been already completed and the reconstructive procedure could be started $[8,11,27,31]$. In case of positive resection margins or lymph node metastasis, either radical hysterectomy or primary chemo-radiotherapy should be performed [8,10,23,27,29,31-33].

Perioperative morbidity rates in young CC patients treated with radical trachelectomy are relatively low and quite acceptable for a radical surgical procedure [8,10,29,30,34]. Moreover, patients have less significant perioperative complications compared with others treated with radical hysterectomy [8,35]. Intraoperative complications are significantly more common in vaginal radical trachelectomy (5.6\%) compared with the abdominal approach $(0.7 \%)[8,10,29,30,34,36]$. On the other hand, postoperative complications are significantly more common in abdominal radical trachelectomy (35\%) compared with vaginal operation $(7.5 \%)$ $[8,10,29,34,36]$. This is mainly because abdominal approach is a more extensive surgical procedure providing wider parametrial resection $[8,10,29,30,34,36]$.

Bladder hypotonia, urinary tract infection, deep venous thrombosis, pulmonary embolism, lymphatic cyst and Genitofemoral nerve palsy, are the most common early postoperative complications in patients having radical trachelectomy $[8,10,23,29,34,36,37]$. Cervical stenosis, chronic pelvic pain and lymphoedema, are the most common late postoperative complications $[8,10,23,34,36]$. Despite differences regarding the width of parametrial resection, both types of radical trachelectomy provide similar oncologic outcomes [ 8,30]. Recurrence rates are quite similar for both surgical approaches, rated at approximately $3.8 \%$ for the abdominal and $4.8 \%$ for the 
vaginal procedure[8,10,16,17,23,29,34,36,38,39]. Mortality rates have small differences, at about $0.4 \%$ for the abdominal and $2.9 \%$ for the vaginal approach $[8,10,16,17,23,29,34,36,38,39]$. In CC patients with stage IB1 disease, radical trachelectomy and radical hysterectomy provide similar disease-free survival rates at 5-years [16].

Tumour size represents a major prognostic factor in young CC patients treated with radical trachelectomy $[8,10,33]$. When using the vaginal procedure in CC patients with tumor size greater than $2 \mathrm{~cm}$, the risk of disease recurrence is more than $12 \%$ (range $12 \%$ to $29 \%$ ) [8-10,17,18,29,33,34,40]. Recent studies regarding abdominal operation in CC patients with tumor size between 2 and $4 \mathrm{~cm}$, have shown very promising results and this is probably because of the wider parametrial resection $[8,17,32,40]$. There are some differences regarding fertility issues among patients treated with radical trachelectomy, based on the type of operation used $[8,10,17,29]$. Pregnancy rates are significantly higher among patients having the vaginal procedure (55\%), compared with others treated with the abdominal approach (16\%) $[8,10,17,29,36,41]$. This could be easily explained by the fact that abdominal radical trachelectomy represents a less conservative approach [8,10,11,16,17,30,39].

Moreover, there are some pregnancy issues (miscarriages and preterm labor) related with the impaired cervical function among patients having radical trachelectomy [3,8,10,17,29,41-43]. First trimester miscarriage rates have significant differences based on the type of operation, at about $12 \%$ for the abdominal and $20 \%$ for the vaginal approach $[8,23,29,36,38,41]$. Second trimester miscarriage rates have also great differences according to the type of procedure, at approximately $12 \%$ for the abdominal and only $3 \%$ for the vaginal operation $[8,23,29,36,41]$. Preterm labor rates are quite similar for both surgical approaches, at approximately $16 \%$ for the abdominal and $18 \%$ for the vaginal procedure $[8,29,36]$. All patients treated with radical trachelectomy should have an elective cesarean section at 38 weeks of gestation, as there is increased risk of uncontrolled cervical injuries during vaginal delivery [29].

In conclusion, radical trachelectomy represents an acceptable treatment option for carefully selected young patients with FIGO stage IB1 CC and strong desire for fertility preservation, without any compromise in oncologic outcome. However, all patients should have a thorough preoperative assessment and a very detailed counseling regarding disease recurrence, oncologic outcome, fertility issues and possible pregnancy complications related with impaired cervical function.

\section{References}

1. WHO (2012) Estimated cancer incidence, mortality and prevalence worldwide in 2012. GLOBOCAN.

2. Ferlay J, Soerjomataram I, Dikshit R, Eser S, Mathers C, et al. (2015) Cancer incidence and mortality worldwide: sources, methods and major patterns in GLOBOCAN 2012. Int J Cancer 136(5): E359-386.

3. NCCN (2007). Clinical Practice Guidelines in Oncology: Cervical Cancer. NCCN org 1-83.
4. Marth C, Landoni F, Mahner S, McCormack M, Gonzalez Martin A, et al. (2017) Cervical cancer: ESMO Clinical Practice Guidelines for diagnosis, treatment and follow-up. Ann Oncol 28(suppl_4).

5. Chuang TL, Feldman S, Nakisige C, Temin S, BerekJS (2016) Management and care of women with invasive cervical cancer: American Society of Clinical Oncology Resource-Stratified Clinical Practice Guideline Summary. Journal of clinical oncology 34(27): 3354-3355.

6. Androutsopoulos G, Kotsopoulos I, Michail G, Decavalas G (2017) Fertility sparing approach in young patients with early stage cervical cancer. Obstetrics \& Gynecology International Journal 6(2): 00197.

7. Androutsopoulos G, Kotsopoulos I, Korompelis P, Decavalas G (2017) Does conservative surgical management of early stage cervical cancer represent a persistent dilemma in young patients? Open Access J Surg 3(3): 1-3.

8. Androutsopoulos G, Naik R (2019) Standard and novel surgical treatment in cervical cancer. In: Farghaly S (Edt.), Uterine cervical cancer: clinical and therapeutic perspectives: Springer.

9. Dargent D, Martin X, Sacchetoni A, Mathevet P (2000) Laparoscopic vaginal radical trachelectomy: a treatment to preserve the fertility of cervical carcinoma patients. Cancer 88(8): 1877-1882.

10. Schneider A, Erdemoglu E, Chiantera V, Reed N, Morice P, et al. (2012) Clinical recommendation radical trachelectomy for fertility preservation in patients with early-stage cervical cancer. Int J Gynecol Cancer 22(4): 659-666.

11. Abu Rustum NR, Sonoda Y, Black D, Levine DA, Chi DS, et al. (2006) Fertility-sparing radical abdominal trachelectomy for cervical carcinoma: technique and review of the literature. Gynecol Oncol 103(3): 807-813.

12. Marth C, Landoni F, Mahner S, McCormack M, Gonzalez Martin A, et al. (2017) Cervical cancer: ESMO Clinical Practice Guidelines for diagnosis, treatment and follow-up. Ann Oncol 28(Suppl 4): iv72-83.

13. Cibula D, Pötter R, Planchamp F, Avall Lundqvist E, Fischerova D, et al. (2018) The European Society of Gynaecological Oncology/European Society for Radiotherapy and Oncology/European Society of Pathology Guidelines for the Management of Patients with Cervical Cancer. Int J Gynecol Cancer 28(4): 641-55.

14. Dargent D, Brun J, Roy M (1994) La trache'-lectomie élargie (TE), une alternative a' l'hyste' rectomie radicale dans le traitement des cancers infiltrants de'veloppe's sur la face externe du col ute'rin. JOBGYN 2: 285-292.

15. Smith JR, Boyle DC, Corless DJ, Ungar L, Lawson AD, et al. (1997) Abdominal radical trachelectomy: a new surgical technique for the conservative management of cervical carcinoma. Br J Obstet Gynaecol 104(10): 1196-1200.

16. Diaz JP, Sonoda Y, Leitao MM, Zivanovic O, Brown CL, et al. (2008) Oncologic outcome of fertility-sparing radical trachelectomy versus radical hysterectomy for stage IB1 cervical carcinoma. Gynecol Oncol 111(2): 255-260.

17. Cao DY, Yang JX, Wu XH, Chen YL, Li L, et al. (2013) Comparisons of vaginal and abdominal radical trachelectomy for early-stage cervical cancer: preliminary results of a multi-center research in China. Br J Cancer 109(11): 2778-2782.

18. Chan K, Naik R (2008) Advances in surgical treatment of cervical cancer. Women's Health (Lond) 4(3): 245-256.

19. Ramirez PT, Pareja R, Rendón GJ, Millan C, Frumovitz M, et al. (2014) Management of low-risk early-stage cervical cancer: should conization, simple trachelectomy, or simple hysterectomy replace radical surgery as the new standard of care? Gynecol Oncol 132(1): 254-259.

20. Bentivegna E, Gouy S, Maulard A, Chargari C, Leary A, et al. (2016) Oncological outcomes after fertility-sparing surgery for cervical cancer: a systematic review. Lancet Oncol 17(6): e240-253. 
21. Viswanathan AN, Deavers MT, Jhingran A, Ramirez PT, Levenback C, et al. (2004) Small cell neuroendocrine carcinoma of the cervix: outcome and patterns of recurrence. Gynecol Oncol 93(1): 27-33.

22. Young R, Clement P (2002) Endocervical adenocarcinoma and its variants: their morphology and differential diagnosis. Histopathology 41(3): 185-207.

23. Hauerberg L, Høgdall C, Loft A, Ottosen C, Bjoern SF, et al. (2015) Vaginal Radical Trachelectomy for early stage cervical cancer. Results of the Danish National Single Center Strategy. Gynecol Oncol 2015; 138(2): 304-310.

24. Peppercorn P, Jeyarajah A, Woolas R, et al. (1999) Role of MR imaging in the selection of patients with early cervical carcinoma for fertilitypreserving surgery: initial experience. Radiology 212(2): 395-399.

25. Balleyguier C, Sala E, Da Cunha T, Bergman A, Brkljacic B, et al. (2011) Staging of uterine cervical cancer with MRI: guidelines of the European Society of Urogenital Radiology. Eur Radiol 21(5): 1102-1110.

26. Lakhman Y, Akin O, Park KJ, Sarasohn DM, Zheng J, et al. (2013) Stage IB1 cervical cancer: role of preoperative MR imaging in selection of patients for fertility-sparing radical trachelectomy. Radiology 69(1) 149-158.

27. Ungár L, Pálfalvi L, Hogg R, Siklós P, Boyle DC, et al. (2005) Abdominal radical trachelectomy: a fertility-preserving option for women with early cervical cancer. BJOG 2005; 112(3): 366-369.

28. Lopes T, Spirtos N, Naik R (2010) Cervical cancer. Bonney's Gynaecological Surgery: Wiley-Blackwell 192-215.

29. Plante M, Gregoire J, Renaud MC, Roy M (2011) The vaginal radical trachelectomy: an update of a series of 125 cases and 106 pregnancies. Gynecol Oncol 121(2): 290-297.

30. Einstein MH, Park KJ, Sonoda Y, Carter J, Chi DS, et al. (2009) Radical vaginal versus abdominal trachelectomy for stage IB1 cervical cancer: a comparison of surgical and pathologic outcomes. Gynecol Oncol 112(1): 73-77.

31. Ungar L, Palfalvi L, Boyle D (2011) Radical abdominal trachelectomy. An atlas of gynecologic oncology: CRC Press 97-104.

32. Wethington SL, Sonoda Y, Park KJ, Alektiar KM, Tew WP, et al. (2013) Expanding the indications for radical trachelectomy: a report on 29 patients with stage IB1 tumors measuring 2 to 4 centimeters. Int J Gynecol Cancer 23(6): 1092-1098.

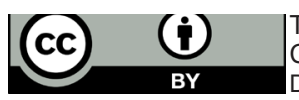

This work is licensed under Creative Commons Attribution 4.0 Licens DOI: 10.19080/OAJS.2018.10.555776
33. Plante M, Roy M (2011) Radical vaginal trachelectomy. An atlas of gynecologic oncology 88-96.

34. Lanowska M, Mangler M, Spek A, Grittner U, Hasenbein K, et al. (2011) Radical vaginal trachelectomy (RVT) combined with laparoscopic lymphadenectomy: prospective study of 225 patients with early-stage cervical cancer. Int J Gynecol Cancer 21(8): 1458-1464.

35. Alexander Sefre F, Chee N, Spencer C, Menon U, Shepherd JH (2006) Surgical morbidity associated with radical trachelectomy and radical hysterectomy. Gynecol Oncol 101(3): 450-454.

36. Pareja R, Rendón GJ, Sanz Lomana CM, Monzón O, Ramirez PT (2013) Surgical, oncological, and obstetrical outcomes after abdominal radical trachelectomy-a systematic literature review. Gynecol Oncol 131(1): 77-82.

37. Kucukmetin A, Biliatis I, Ratnavelu N, Patel A, Cameron I, et al. (2014) Laparoscopic radical trachelectomy is an alternative to laparotomy with improved perioperative outcomes in patients with early-stage cervical cancer. Int J Gynecol Cancer 24(1):135-140.

38. Gien L, Covens A (2010) Fertility-sparing options for early stage cervical cancer. Gynecol Oncol 117(2): 350-357.

39. Okugawa K, Kobayashi H, Sonoda K, Kaneki E, Kawano Y, et al. (2017) Oncologic and obstetric outcomes and complications during pregnancy after fertility-sparing abdominal trachelectomy for cervical cancer: a retrospective review. Int J Clin Oncol 22(2): 340-346.

40. Lintner B, Saso S, Tarnai L, Novak Z, Palfalvi L, et al. (2013) Use of abdominal radical trachelectomy to treat cervical cancer greater than $2 \mathrm{~cm}$ in diameter. Int J Gynecol Cancer 23(6): 1065-1070.

41. Speiser D, Mangler M, Köhler C, Hasenbein K, Hertel H, et al. (2011) Fertility outcome after radical vaginal trachelectomy: a prospective study of 212 patients. Int J Gynecol Cancer 21(9): 1635-1639.

42. Kasuga Y, Nishio H, Miyakoshi K, Sato S, Sugiyama J, et al. (2016) Pregnancy Outcomes After Abdominal Radical Trachelectomy for Early-Stage Cervical Cancer: A 13-Year Experience in a Single Tertiary Care Center. Int J Gynecol Cancer 26(1): 163-168.

43. Boss EA, van Golde RJ, Beerendonk CC, Massuger LF (2005) Pregnancy after radical trachelectomy: a real option? Gynecol Oncol 99(3 Suppl 1): S152-156.

\section{Your next submission with Juniper Publishers} will reach you the below assets

- Quality Editorial service

- Swift Peer Review

- Reprints availability

- E-prints Service

- Manuscript Podcast for convenient understanding

- Global attainment for your research

- Manuscript accessibility in different formats

( Pdf, E-pub, Full Text, Audio)

- Unceasing customer service

Track the below URL for one-step submission https://juniperpublishers.com/online-submission.php 